\title{
One Dimensional Transient State Finite Element Model to Study Thermal Variations due to Transient Vasoconstriction followed by Persistent Vasodilation during Inflammation in Surgical Wound of Peripheral Tissues of Human Limb
}

\author{
N. Gupta* and M. Shakya \\ Department of Mathematics and Computer Applications, Maulana Azad National Institute of Technology, \\ Bhopal - 462003, Madhya Pradesh, India; \\ namrata280773@yahoo.com, madhvishakya@yahoo.co.in
}

\begin{abstract}
Objectives: This paper compares theoretically the thermal variations in normal tissues, clean surgical wound and contaminated surgical wound in peripheral tissues of human arm and leg during inflammatory phase of healing. Methods/ Statistical Analysis: One dimensional finite element model is developed using Bio-heat equation.Values of arterial blood temperature, core body temperature and heat transfer coefficient have been revised. During inflammation blood perfusion rate and metabolic heat generation rate are considered linearly dependent on temperature and spatial coordinate, and exponentially dependent on time.The effect of vasodilation and effect of rate at which vascular changes occur, on temperature profiles,is investigated by varying value of linear coefficient of temperature dependence and coefficient of time variable respectively. Findings: A computer programme in MATLAB is developed to simulate the results. Skin surface temperature in normal tissue are simulated and validated from published experimental data. Maximum blood perfusion rate at maximum vasodilation calculated theoretically is validated with the published experimental data. Temperature difference in contaminated wound and normal tissue are simulated and validated with the published experimental data. Improvements/Applications: Normal skin temperature and thermal variations during vasodilation are modelled well by revising the values of parameters mentioned above and considering temperature dependent parameters.This information may be useful to biomedical scientists in development of treatment regimen for surgical wounds.
\end{abstract}

Keywords: Finite Element Technique ,Non-linear Partial Differential Equation, Temperature Dependent Blood Perfusion Rate, Temperature Dependent Metabolic Heat Generation Rate, Thermal Variations in Peripheral Tissues of Human Limb, Vasodilation

\section{Introduction}

Healing is a systematic process, traditionally explained in terms of four overlapping classic phases: hemostasis, inflammation, proliferation, and maturation $\underline{\underline{1-3}}$. It occurs at normal core body temperature and a body surface temperature lying in a particular range $e^{4}$. Any disturbance in appropriate thermal environment may complicate the wound healing process or may lead to wound infection. Perioperative hypothermia increases risk of surgical wound infection by several mechanisms including cutaneous vasoconstriction and a decrease in the activity of the immune system ${ }^{5}$. Thus the precise monitoring of spatial distribution of thermal histories in biological systems that are produced during a treatment protocol is essential in many diagnostic and therapeutic applications ${ }^{6}$.

${ }^{*}$ Author for correspondence 
Analysis of thermal variations in biological tissues has become possible after the pioneer work done $e^{7,8}$. Since then the problem of heat transfer in biological systems under different physiological and environmental conditions has been dealt with by either performing experimental investigations or by developing and analysing theoretical model ${ }^{6,9-16}$.It was observed by ${ }^{17}$ that peripheral temperatures of different segments in human body vary widely in cold. They reported the maximum difference in skin temperature (toe-forehead) to be $17^{\circ} \mathrm{C}$ during cold stress. It is thus reflected that representation of peripheral temperature of different segments of human body in cold environment through weighted mean skin temperature is not at all justified and may mislead in medication protocols. Though skin temperature at different location in human body at different environmental conditions are available in the literature but temperature profile of skin and subcutaneous tissue of human arm and leg separately during inflammation at different blood perfusion rates (post surgery) is hardly available.

Thus a need to develop a theoretical model to predict temperature profiles of peripheral tissues of human limb post surgery is strongly felt. Further, the theoretical estimate of the probable difference in temperature of normal skin and the temperature of wound bed undergoing inflammation at different blood perfusion levels may also be used as the baseline for differentiating healing wound from non-healing wound. A few mathematical models have been developed to study nodal temperature in surgical wound during healing process by incorporating time dependent physiological parameters $\frac{18-21}{}$. But it has not been performed separately for skin and subcutaneous tissue of human arm and leg undergoing inflammation by considering temperature dependent physiological parameters till date.

In this paper, an axisymmetric one dimensional finite element model has been developed by using Pennes' Bioheat equation ${ }^{7}$ to study the effect of persistent vasodilation on skin and subcutaneous tissue temperature distribution in clean and contaminated surgical wound $\frac{3,22}{2}$ of human limb undergoing healing from hemostasis to inflammation.It has been done by incorporating temperature dependent blood perfusion rate and metabolic heat generation rate. Metabolic heat generation rate has been approximated as linearly dependent on temperature from the Van't Hoff $Q_{10}$ effect with a sensitivity coefficient of two $\mathrm{O}^{23,24}$ and linearly on spatial coordinate in normal tissue $^{20}$. In abnormal tissue, it is exponential function of time too. Blood perfusion rate is considered dependent linearly on spatial coordinate in normal tissue $e^{20}$. In clean and contaminated wound tissue blood perfusion rate is considered to be dependent exponentially on time and linearly on temperature ${ }^{20,16}$ as well. The analysis of thermal variation in wounded peripheral tissue due to vascular changes and the rate of occurrence of vascular changes is studied by varying the linear coefficient of temperature dependence of blood perfusion rate and the coefficient of time variable in exponential function of time. The effect of venous counter current heat exchange on arterial blood temperature and core body temperature has been considered in this study. The muscle set point temperature in the limb is used as the core temperature $T_{c}$ for the peripheral tissues of the limb ${ }^{25}$. Convective and radiative heat transfer coefficients and evaporative heat loss have been improved. Mixed convective heat transfer coefficient has been calculated by considering the effect of difference in skin surface temperature and ambient temperature and moderate air velocity ${ }^{24}$. Radiative heat transfer coefficient $h_{\text {rad }}$ for limb has been taken from the work of ${ }^{26}$. Value of evaporative heat loss is taken from ${ }^{17}$. Dermis and epidermis thickness has been revised to make the model more realistic.

The rest of the paper is organised as follows. Section 2 deals with the biological background of the problem, its mathematical and variational formulation. In section 3 , finite element model has been developed to find the solution to the variational form of the equation. Results have been discussed and validated in section 4 followed by conclusion in section 5 .

\section{Model Descriptions}

\section{Nomenclature}

\begin{tabular}{|l|l|}
\hline Symbols & \\
\hline$c$ & Specific heat in cal $/ \mathrm{gm} /{ }^{\circ} \mathrm{C}$ \\
\hline$E$ & Evaporative heat loss rate in $\mathrm{Cal} / \mathrm{cm}^{2} / \mathrm{min}$ \\
\hline$h$ & Heat transfer coefficient in $\mathrm{Cal} / \mathrm{cm}^{2} / \mathrm{min} /{ }^{\circ} \mathrm{C}$ \\
\hline$K$ & Thermal conductivity in $\mathrm{Cal} / \mathrm{cm} / \mathrm{min} /{ }^{\circ} \mathrm{C}$ \\
\hline$l$ & Regression coefficients \\
\hline$n$ & Normal to skin surface \\
\hline$R$ & $\begin{array}{l}\text { Spatial coordinate originating from the centre } \\
\text { of the limb in cm }\end{array}$ \\
\hline$R_{1}, R_{12}$ & $\begin{array}{l}\text { Spatial coordinate of skin core and skin } \\
\text { surface respectively in cm }\end{array}$ \\
\hline$r$ & Thickness of peripheral tissues in cm \\
\hline
\end{tabular}




\begin{tabular}{|c|c|}
\hline $\bar{r}$ & Local radial coordinate in $\mathrm{cm}$ \\
\hline$S$ & $\begin{array}{l}\text { Metabolic heat generation rate in } \mathrm{Cal} / \mathrm{cm}^{3} / \\
\min \end{array}$ \\
\hline$T$ & Unknown temperature of tissue in ${ }^{\circ} \mathrm{C}$ \\
\hline$T_{a}, T_{b, e f f}, T_{c}$ & $\begin{array}{l}\text { Atmospheric, effective arterial blood and core } \\
\text { temperature respectively in }{ }^{\circ} \mathrm{C}\end{array}$ \\
\hline$T^{(e)}$ & Temperature in $\mathrm{e}^{\text {th }}$ element \\
\hline $\bar{T}^{(e)}$ & Nodal temperature matrix of $\mathrm{e}^{\text {th }}$ element \\
\hline$T_{o}$ & $\begin{array}{l}\text { Tissue temperature at thermo-neutrality state } \\
\text { in }{ }^{\circ} \mathrm{C}\end{array}$ \\
\hline$t$ & Time in min \\
\hline$\alpha_{0(1)}$ & $\begin{array}{l}\text { Unknown constants used to find linear } \\
\text { expression for } \omega_{0} \text { in dermis }\end{array}$ \\
\hline$\gamma, \gamma_{a b}$ & $\begin{array}{l}\text { Linear coefficient of temperature dependence } \\
\text { in normal and abnormal tissue }\end{array}$ \\
\hline$\eta_{o(1)}$ & $\begin{array}{l}\text { Unknown constants to determine time } \\
\text { function in blood perfusion rate in abnormal } \\
\text { tissue }\end{array}$ \\
\hline$v_{o(1)}$ & $\begin{array}{l}\text { Unknown constants to determine time } \\
\text { function in metabolic heat generation rate in } \\
\text { abnormal tissue }\end{array}$ \\
\hline$\phi(t)$ & $\begin{array}{l}\text { Time factor in blood perfusion rate in } \\
\text { abnormal tissues }\end{array}$ \\
\hline$\rho$ & Density of tissue in $\mathrm{gm} / \mathrm{cm}^{3}$ \\
\hline$\psi(t)$ & $\begin{array}{l}\text { Time factor in metabolic heat generation rate } \\
\text { in abnormal tissues }\end{array}$ \\
\hline$\Omega^{(e)}$ & Domain of the $\mathrm{e}^{\text {th }}$ element \\
\hline$\omega, \omega_{o}$ & $\begin{array}{l}\text { Blood perfusion rate and baseline blood } \\
\text { perfusion rate in } \mathrm{ml} / \mathrm{cm}^{3} / \mathrm{min}\end{array}$ \\
\hline \multicolumn{2}{|c|}{ Subscripts and superscript } \\
\hline$a$ & Air \\
\hline$a b$ & Abnormal \\
\hline atm & Atmospheric \\
\hline$b$ & Blood \\
\hline bas & Baseline value \\
\hline cnv & Convective \\
\hline diff & Difference \\
\hline$e$ & $e^{\text {th }}$ element \\
\hline$e q$ & Equilibrium \\
\hline frc & Forced \\
\hline $\max$ & Maximum \\
\hline $\operatorname{mix}$ & Mixed \\
\hline nat & Natural \\
\hline nor & Normal \\
\hline rad & Radiative \\
\hline
\end{tabular}

\begin{tabular}{|l|l|}
\hline sk & Skin \\
\hline sub, der, epi & Subcutaneous, dermis and epidermis \\
\hline
\end{tabular}

\subsection{Biological Background}

Peripheral tissue of human limb can be broadly divided into three layers: epidermis, dermis and subcutaneous tissue. Epidermis contains neither any heat source nor any blood vessels ${ }^{23}$. Dermis is the region where blood vessel density gradually increases till the interface of dermis and subcutaneous tissue and is almost same there. During surgery a cut is made into the skin tissue which results in vascular injury ${ }^{20}$. This wound is affected by temperature through its relationship with perfusion and the host immune response ${ }^{5}$. Immediately after an incision, hemostasis is achieved by any one or a combination of several mechanisms ${ }^{27}$ : (1) vascular constriction, (2) formation of platelet plug, (3) formation of blood clot and (4) eventual growth of fibrous tissue into the blood clot to close the hole in the vessel permanently ${ }^{28,29}$. Vasoconstriction results from (1) local myogenic spasm, (2) local autacoid factors from the traumatized tissues and blood platelets, and (3) nervous reflexes ${ }^{29}$. Both sensory afferent nerves and autonomic nerves are in abundance in dermal and subdermal region of limb and also innervate blood vessels. $45 \%$ of cutaneous afferent nerves are responsive to mechanical and heat stimulation ${ }^{30}$. Vasoconstriction via autonomic nervous system is achieved by increased noradrenergic vasoconstrictor tone by releasing both norepinephrine and cotransmitters (including neuropeptide $\mathrm{Y})^{30-32}$. It can also be achieved from local myogenic contraction of blood vessels through the release of endothelin from damaged endothelium ${ }^{29,33}$. It is activated by calcium ions, and Adenosine Triphosphate (ATP) is degraded to Adenosine Diphosphate (ADP) to provide energy for contraction $^{29}$. In case of smaller vessels, the platelets are responsible for much of the vasoconstriction by releasing a vasoconstrictor substance, thromboxane $\mathrm{A}_{2}{ }_{29}$. This instantaneously reduces the flow of blood from the ruptured vessel.

If the surgical wound is clean, no inflammation is encountered ${ }^{22}$. In case of contaminated surgical wound, a series of complex biochemical reactions take place at molecular level and lead to redness, heat, swelling and pain, marking the entry into inflammatory stage of

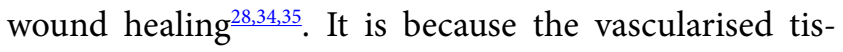
sues experience increased perfusion as a consequence of vasodilation $\underline{6}$ during inflammation $\frac{27,29,29,34,35}{}$. It could 
be achieved by the release of vasodilator substance (for e.g. nitric oxide) by endothelial cells. The smooth muscles which surround terminal arterioles relax which result in increased blood flow into the connective tissue capillary bed. Endothelial cells also increase leakiness and enhance leukocyte adhesiveness and participate in immune responses ${ }^{33}$. The relaxation of smooth muscles to achieve vasodilation may also occur in response to lack of oxygen in the local tissues due to increased metabolic activity after initiation of healing process ${ }^{29,36,37}$. It may also occur due to excess carbon dioxide, increased hydrogen ion concentration, formation of vasodilator substances (adenosine, carbon dioxide, adenosine phosphate compounds, histamine, potassium ions, hydrogen ions, nitric oxide and etc.) and their diffusion from the tissue in response to oxygen deficiency. Formation of adenosine from ATP $\underline{29}$ is accompanied by release of heat energy ${ }^{38}$ and requirement of ATP derived energy sources for endothelium dependent arterial relaxation is reported by ${ }^{39,40}$.

Above mentioned literature review suggests that heat energy released from complex biochemical reactions occurring with the onset of wound healing process results in vasodilation after a transient vasoconstriction. This vasodilation in turn causes warmth, as blood carries body heat from the body's core to cooler peripheral tissues ${ }^{34,35}$. Hence effect of vasodilation is incorporated by considering blood perfusion linearly dependent on temperature $e^{6,14,16}$.

\subsection{Mathematical Formulation}

For one dimensional axisymmetric transient state case, Pennes' bio heat equation for heat flow in tissues of peripheral human limb in polar coordinates takes the form:

$K\left(\frac{\partial^{2} T}{\partial R^{2}}+\frac{1}{R} \frac{\partial T}{\partial R}\right)+c_{b} \rho_{b} \omega(r, T, t)\left(T_{b, e f f}-T\right)+S(r, T, t)=\rho c \frac{\partial T}{\partial t}$

Here $K, c_{b} \rho_{b} \rho, c, T, T_{b, e f f}$, and $\left(R=R_{1}+r\right.$, where $R_{1}$ and $r$ are the spatial coordinate of core and the thickness of the peripheral tissues respectively)are thermal conductivity, blood specific heat, blood density, tissue density, tissue specific heat, unknown tissue temperature, effective arterial blood temperature (explained in section 2.2.3) and spatial coordinate respectively. $\omega(r, T, t)$ is the blood perfusion rate (explained in section 2.2.1).S(r,T,t)is the basal metabolic heat generation rate $\left(\mathrm{Cal} / \mathrm{min} / \mathrm{cm}^{3}\right)$ (explained in section 2.2.2).

\subsubsection{Blood Perfusion Rate}

In thermally neutral state blood is perfused in tissue at basal rate $\omega_{o}$. In non-neutral conditions or during progression of healing, local blood perfusion rate may depend on local temperature through internal physiological influences ${ }^{3}$. It is expressed as

$$
\omega(r, T, t)=\omega_{o}(r) *\left(1+\gamma_{a b} T\right) * \phi(t)
$$

Here $\omega_{o}\left(\mathrm{ml} / \mathrm{cm}^{3} / \mathrm{min}\right)$ is the baseline perfusion at thermo-neutral state, $\gamma_{a b}$ is the linear coefficient of temperature dependence ${ }^{(6,14,16)}$ and $\phi(t)$ is the temporal component of blood perfusion rate ${ }^{19-21}$.

Normal tissues:In this study normal tissue do not undergo any inflammation(vasodilation)i.e. $\gamma_{a b}=0$. Also, it is assumed that $\phi(t)=1$. Since this study has been conducted for ambient temperature of $15^{\circ} \mathrm{C}$, which is far below the range of thermo-neutral state, basal blood perfusion rate in normal peripheral tissue is assumed to be lower than that at thermo-neutral state.Due to the anatomy of blood vessels in the peripheral tissue, the value of blood perfusion rate in subcutaneous tissue at $15^{\circ} \mathrm{C}$ ambient temperature is assumed to be half of the baseline perfusion in fat reported by ${ }^{24}$. In epidermis it is assumed to be zero. In dermis blood perfusion rate is assumed to be space dependent and is expressed by linear interpolation between half of the reported value at dermis at thermoneutral state $\omega_{d e r}$ by ${ }^{24}$ and the value at epidermis $\frac{19,20}{}$.

$$
\begin{aligned}
& \omega_{o, \text { der }}(r)=\sum_{i=0}^{1} \alpha_{i} R^{i}, \alpha_{o}=\left(\left(\omega_{\text {der }} R_{11}-\omega_{\text {epi }} R_{7}\right) /\left(R_{11}-R_{7}\right)\right), \\
& \alpha_{1}=\left(\left(\omega_{\text {epi }}-\omega_{\text {der }}\right) /\left(R_{11}-R_{7}\right)\right)
\end{aligned}
$$

Abnormal Tissues: Due to loss of blood and tissues during surgery and vasoconstriction in blood vessels, it is assumed that at time $\mathrm{t}=0$ blood perfusion rate is negligible. After a few minutes, vasoconstriction is followed by vasodilation to fulfil the requirements of wounded region. The delay in re-assumption of perfusion rate is incorporated in the model by introducing a time factor $\phi(t)$ in the expression for blood perfusion rate $\mathrm{e}^{19,20}$. The effect of vasodilation on thermal variation is seen by increasing the value of the parameter $\gamma_{\mathrm{ab}}$. In abnormal tissue, perfusion rate is given by eq. 2 . $\omega_{\mathrm{o}}$ in dermis is given by eq. (3) and

$$
\phi(t)=\left(\eta_{o}^{e}+\eta_{1}^{e} e^{-\eta t}\right) \quad, \quad \phi(0)=0, \phi(\infty)=1
$$

The effect of the rate at which vascular change occurs is studied by varying value of the parameter $\eta$.The effect 
of vasodilation is studied by varying the parameter $\gamma_{a b}{ }^{6}$, $\underline{14,16}$.

\subsubsection{Metabolic Heat Generation Rate}

Metabolic heat generation rate is given by

$$
S(r, T, t)=S(r) * S(T) * \psi(t)
$$

Normal tissue: Here $\psi(t)$ is unity for normal tissue. $S(T)$ within a tissue volume is considered to be the sum of the basal metabolic rate $S_{b a s}\left(\mathrm{Cal} / \mathrm{min} / \mathrm{cm}^{3}\right)$ and additional heat gain due to changes in the local basal metabolism during non thermo-neutral environment $\delta S_{\text {bas }} \underline{24}$.

$$
S(T)=s_{b a s}+\delta s_{b a s}(T)
$$

In ${ }^{24}$ observed that the changes in local basal metabolism is a function of local tissue temperature which accounts for the dependence of biochemical reaction on tissue temperature and is given by

$$
\delta s_{\text {bas }}=s_{\text {bas }}\left[2^{\left(T-T_{o}\right) / 10}-1\right]
$$

Here $T_{o}$, the tissue temperature at thermo-neutral state is the reference temperature. Using equation (7) in equation (6), we get,

$$
S(T)=S_{b a s}\left[2^{\left(T-T_{o}\right) / 10}\right]
$$

In this paper, an expression for $S(T)$ has been derived from linear approximation of equation (8). $S_{b a s}$ for subcutaneous has been taken from ${ }^{24}$. In epidermis $S_{b a s}$ is assumed to be negligible. In dermis $S_{b a s}$ is linearly interpolated between the reported value at dermis by Fiala and epidermal value through $S(r) . S(r)$ is one in subcutaneous tissue, negligible in epidermis and linear function of $r$ in dermis. The set point $T_{o}$ for subcutaneous, and dermis of arm and leg is obtained from the work of ${ }^{25}$ for reclining person exposed to steady state thermo-neutral conditions of $30^{\circ} \mathrm{C}$. Thus we get,

$$
S_{i}(T)=s_{i, 1}+s_{i, 2} T, \quad i=s u b, \text { der }
$$

Abnormal tissue: Here $\psi(\mathrm{t})$ is an exponential function of time $\mathrm{e}^{20,21}$,

$$
\psi(t)=\left(v_{o}^{e}+v_{1}^{e} e^{-v t}\right) \quad, \quad \psi(0)=1 / 20, \psi(\infty)=1
$$

and $S(T)$ and $S(r)$ are the same as in case of normal tissue.

\subsubsection{Arterial Blood Temperature and Core Body}

\section{Temperature}

It is assumed here that during the passage of arterial blood from central blood pool till the muscle of the limb, the venous counter-current heat exchange between pairs of adjacent arteries and veins $\frac{23,24}{2}$ on arterial blood supply has already occurred and the effective arterial blood temperature $T_{b, e f f}$ is same as the muscle set point temperature for limb ${ }^{25}$.Also muscle set point temperature in the limb acts as the core temperature $T_{c}$ for the peripheral tissues of the limb.

$$
T\left(R_{1}, t\right)=T_{c} \quad \forall \quad t \geq 0
$$

\subsubsection{Heat Exchange with the Environment}

The outer surface of skin is exposed to the atmosphere and heat is lost from this surface through convection, radiation and evaporation $\frac{17,24,25}{}$ through the skin. This boundary condition is formulated as

$-\left.K \frac{\partial T}{\partial n}\right|_{\text {as surface }}=h_{c m b}\left(T-T_{a t m}\right)+E \quad \forall t>0$

Here $T_{a t m}, \partial T / \partial n$ and $E$ are atmospheric temperature, partial derivative of unknown tissue temperature along the normal direction to the skin surface and $E$ is the evaporative heat loss $\left(\mathrm{Cal} / \mathrm{cm}^{2} / \mathrm{min}\right) . \mathrm{h}_{\mathrm{cmb}}$ is combined heat transfer coefficient given by $\underline{\underline{23}}$

$$
h_{c m b}=h_{\text {rad }}+h_{c n v}
$$

where $h_{r a d}$ and $h_{c n v}$ are radiative and convective heat transfer coefficients respectively. Convective heat transfer coefficient $h_{c n v}$ has been calculated for moderate air velocity from the equation given by $\underline{24}$

$$
h_{c n v}=\sqrt{l_{\text {nat }} \sqrt{T_{\text {sur }}-T_{a}}+l_{f r c} * v_{a}+l_{\text {mix }}}
$$

where $l_{n a p} l_{f r c} l_{\text {mix }}$ are the regression coefficients for natural, forced, mixed air for limb obtained by regression analysis done by ${ }^{23,24,41-43} . v_{a}$ is the air velocity and $T_{\text {sur }}$ is the limb surface temperature. The values of the required parameters used are given in table 1. Value of radiative heat transfer coefficient $h_{\text {rad }}$ for limb has been taken from the work of ${ }^{26}{ }^{26}$.Value of $E$ has been taken from the work of Werner and Reents ${ }^{17}$.

It is assumed that the outer surface of the human limb is insulated initially and is at core body temperature $T_{c}$ at time $t=0$. Hence the initial condition for the tissue is given by 
$T(R, 0)=T_{c}, \quad \forall R$

\subsection{Variational Formulation}

The variational formulation of equation. (1) is given by

$I=1 / 2 \int_{\Omega}\left\{K(\partial T / \partial r)^{2}+\left(m_{1}+m_{2} T_{b, e f f}\right)\left(T-T_{b, e f f}\right)^{2}-\left(2 S_{1} T+S_{2} T^{2}\right)+\rho c\left(\partial\left(T^{2}\right) / \partial t\right)\right\}^{*}$

$\left(R_{1}+r\right) d r+1 / 3 \int_{\Omega} m_{2}\left(T-T_{b, f f}\right)^{3}\left(R_{1}+r\right) d r+\left[\left(\left(R_{1}+r\right) / 2\right)\left\{h_{\text {conb }}\left(T-T_{a}\right)^{2}+2 E T\right\}\right]_{r=r_{\text {ser }}}(16)$

where $m_{1}=c_{b} \rho_{b} \omega_{o} \phi(t), m_{2}=c_{b} \rho_{b} \omega_{o} \gamma \phi(t)$,

$S_{1}=S(r) S_{1} \psi(t), S_{2}=S(r) s_{2} \psi(t)$

$R=R_{1}+r, 0 \leq r \leq R_{12}-R_{1}$

and $\Omega$ is the complete domain under consideration.

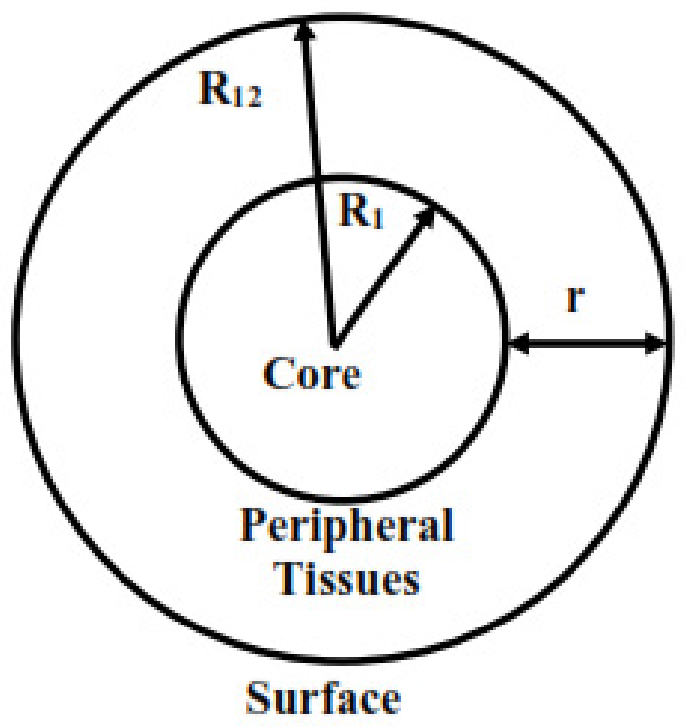

(a)

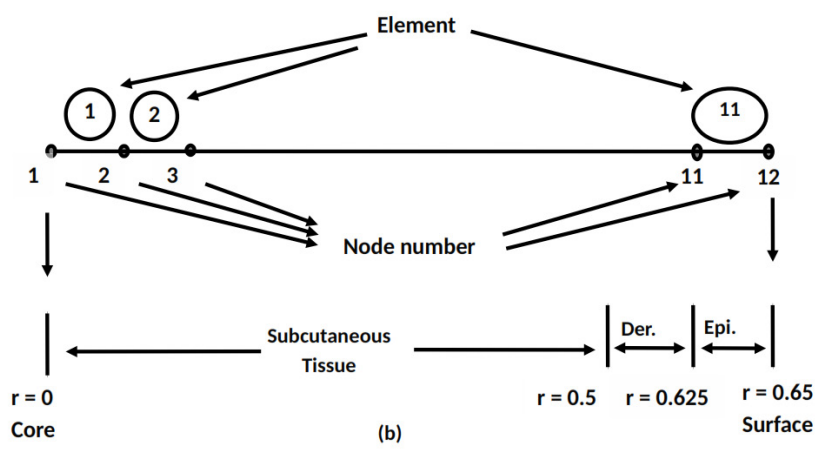

Figure 1 a.Annular shaped domain of peripheral tissues b. Discretised domain for analogous axisymmetric one dimensional problem with 11 elements and 12 nodes

\section{Use of Finite Element Method}

\subsection{Discretisation of Domain}

The region under consideration is discretised into eleven elements and twelve nodes are shown in Figure 1a and $1 b)$. Length of each of five subcutaneous elements is 0.1 $\mathrm{cm}$ and that of five dermal and one epidermal element each is $0.025 \mathrm{~cm}$. The discretised form of eq. (16) is given by

$$
\begin{aligned}
& I^{(e)}=1 / 2 \int_{\Omega^{(e)}}\left\{K^{(e)}\left(\partial T^{(e)} / \partial \bar{r}\right)^{2}+\left(m_{1}^{(e)}+m_{2}^{(e)} T_{b, e f f}\right)\left(T^{(e)}-T_{b, e f f}\right)^{2}-\left(2 S_{1}^{(e)} T^{(e)}+S_{2}^{(e)} T^{(e) 2}\right)\right. \\
& \left.+\rho c\left(\partial\left(T^{(e)}\right)^{2} / \partial t\right)\right\} *\left(R_{1}+\bar{r}\right) d \bar{r}+1 / 3 \int_{\Omega^{(e)}} m_{2}^{(e)}\left(T^{(e)}-T_{b, e f f}\right)^{3}\left(R_{1}+\bar{r}\right) d \bar{r} \\
& +\lambda^{(e)}\left[\left(\left(R_{1}+\bar{r}_{j}\right) / 2\right)\left\{h_{c m b}\left(T^{(e)}-T_{a}\right)^{2}+2 E T^{(e)}\right\}\right]_{\bar{r}=\overline{r_{j}}}
\end{aligned}
$$

Here $\bar{r}$ is the local radial coordinate and $\Omega^{(e)}$ is the domain of $e^{\text {th }}$ element

$$
\lambda^{(e)}=\left\{\begin{array}{lr}
1, & \text { for } e=11 \\
0, & \text { other elements }
\end{array}\right.
$$

Using linear shape function in (eq. 17), integral $I^{(e)}$ is evaluated for each element, differentiated with respect to each nodal temperature of the element and minimised. The corresponding global matrix equation is assembled to obtain a non-linear system of ordinary differential equations (NLSODE). Crank Nicolson Technique is applied along with initial condition (eqn. 15) to reduce NLSODE to non linear system of algebraic equations which is then solved by Newton Raphson Method to obtain the tissue temperature at each node for progressive time. A computer program has been developed in MATLAB to simulate the results.

\section{Numerical Results, Validation and Discussion}

The values of physical and physiological parameters taken to obtain the values of $h_{c m b}$ are given in Table $1 \frac{17,24,26}{\text { : }}$

The values of physical and physiological parameters considered to obtain the numerical results are given in Table $2 a$ and $2 b^{17,24,25}$ :

In this paper finite element model is developed by considering temperature dependent (along with spatial coordinate and time) blood perfusion rate and metabolic heat generation rate to incorporate the effect of transient vasoconstriction followed by persistent vasodilation on temperature profiles of peripheral wounded tissues of 


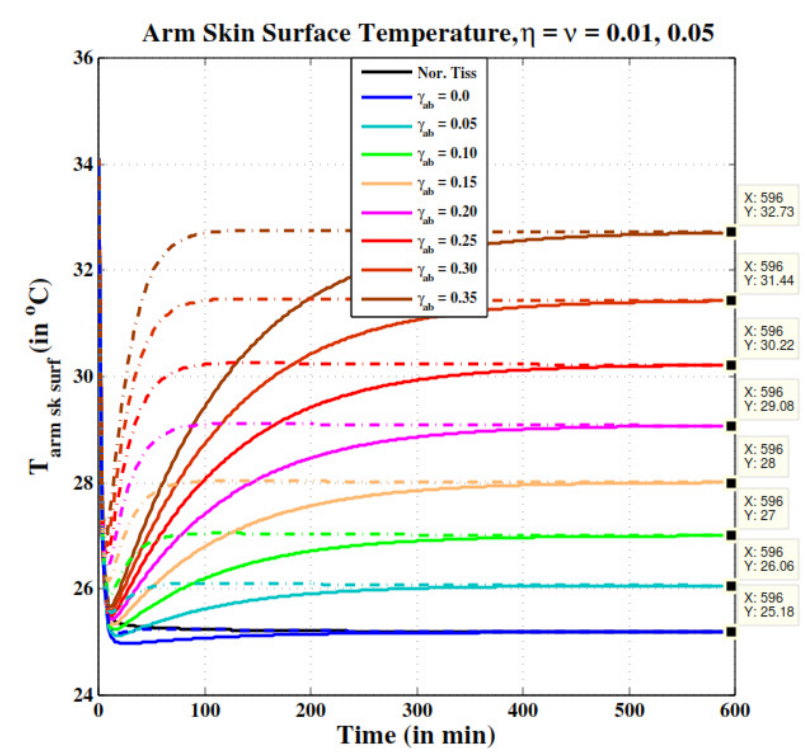

(a)

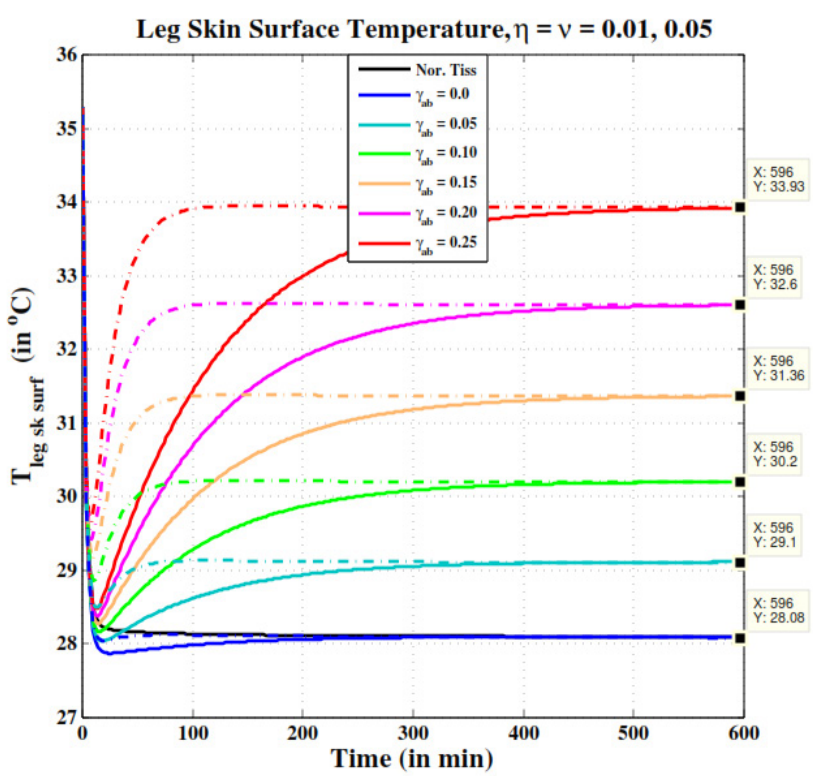

(b)

Figure 2. Skin surface (nodal) temperature $\mathrm{T}$ versus time $\mathrm{t}$ graph for different values of $\gamma_{a b}$ at $T_{a}=15^{\circ} \mathrm{C}$ at $\eta=v=0.01$ (solid line) and 0.05 (dotted dashed line) in (a) arm and (b) leg.

limbundergoing transition from hemostasis to inflammation during healing. Comparison of temperature profiles of two types of wounded tissues: clean surgical wound and contaminated surgical wound of arm and leg has been theoretically done with the normal tissue at different values of the parameters $\gamma_{a b}, \eta$ and $v$. Skin surface temperature versus time graph has been shown in Figure $2 \mathrm{a}$ and $2 \mathrm{~b}$. Mean skin and subcutaneous temperature \pm SD versus time has been plotted in Figure 3a, 3b, 4a, 4b, $5 \mathrm{a}, 5 \mathrm{~b}, 6 \mathrm{a}$ and $6 \mathrm{~b}$. Tissue temperature along the transverse axis i.e. radial distance from core is plotted in Figure 7a and $7 \mathrm{~b}$. In Figure 2 to 7 normal and clean wound tissue $\left(\gamma_{\mathrm{ab}}=0\right)$ temperature has been shown by black and blue colour respectively. Temperature of contaminated wound tissue $\left(\gamma_{\mathrm{ab}}>0\right)$ is shown by other colours. Mean skin blood perfusion rate with SD for arm and leg at different $\gamma_{\mathrm{ab}}$ has been shown in Figure $8 \mathrm{a}$ and $8 \mathrm{~b}$. Mean skin temperature difference of abnormal skin from its normal counterpart with SD for arm and leg at different $\gamma_{\mathrm{ab}}$ has been shown in Figure $9 \mathrm{a}$ and $9 \mathrm{~b}$.

It is assumed that the peripheral tissues are insulated initially and are at core body temperature. At time $t=0$, the condition of insulation is removed and body is exposed to the ambient temperature of $15^{\circ} \mathrm{C}$ which acts as mild cold exposure. It leads to thermo-genesis ${ }^{\underline{44}}$ and induces vasoconstriction ${ }^{30}$ through combined neural and local mechanisms $\frac{31}{}$. Both, thermo-genesis and reduction in skin blood flow due to vasoconstriction significantly affect skin temperature ${ }^{3,30,31,44}$. The effect of thermogenesis on skin temperature in both: normal and abnormal tissue is modelled through temperature dependent metabolic heat generation rate. The effect of vasoconstriction due to cold exposure at an ambient temperature of $15^{\circ} \mathrm{C}$ on temperature profiles is incorporated by assuming basal blood perfusion rate to be half of its value at thermo-neutral state and $\gamma_{\mathrm{ab}}=0$.

Normal tissue- Surface temperature of normal arm and leg tissue, fall steeply from the corresponding core temperature for initial 10-15 minutes and finally stabilises at $25.16^{\circ} \mathrm{C}$ and $28.08^{\circ} \mathrm{C}$ respectively Figure $2(\mathrm{a}-\mathrm{b})$. Steady state surface temperature can also be seen from Figure 7(a-b). Mean skin temperature of normal arm and leg tissue falls to $25.53^{\circ} \mathrm{C}$ is shown in Figure 3(a), 5(a)) and $28.38^{\circ} \mathrm{C}$ in Figure $4(\mathrm{a}), 6(\mathrm{a})$ respectively. Normal mean subcutaneous tissue temperature of arm and leg falls to

Table 1. Values of required parameters for calculating the value of combined convective and radiative heat transfer coefficient

\begin{tabular}{|l|l|l|l|l|l|l|}
\hline Segment & $\boldsymbol{l}_{\text {nat }}$ & $\boldsymbol{l}_{\text {frc }}$ & $\boldsymbol{l}_{\text {mix }}$ & $\boldsymbol{v}_{a}(\mathrm{~cm} / \mathbf{m i n})$ & $\boldsymbol{T}_{\text {sur }}\left({ }^{\circ} \mathrm{C}\right)$ & $\mathrm{h}_{\mathrm{rad}}\left(\mathrm{Cal} / \mathrm{cm}^{2} / \mathrm{min} /{ }^{\circ} \mathrm{C}\right)$ \\
\hline Arm & 8.3 & 216 & -10.8 & 12000 & 25 & 0.0075 \\
\hline Leg & 5.3 & 220 & -11 & 3900 & 28 & 0.0077 \\
\hline
\end{tabular}




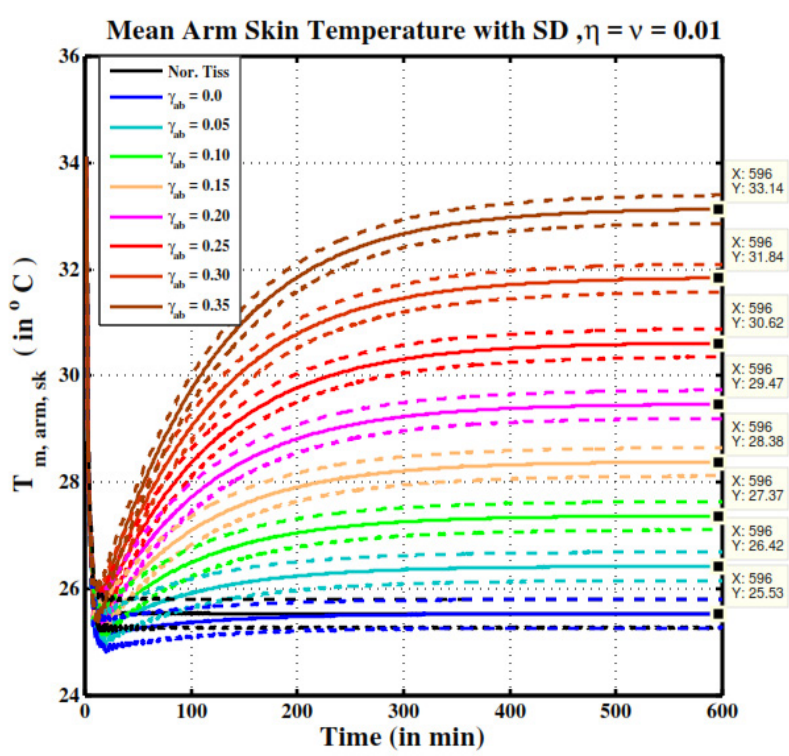

(a)

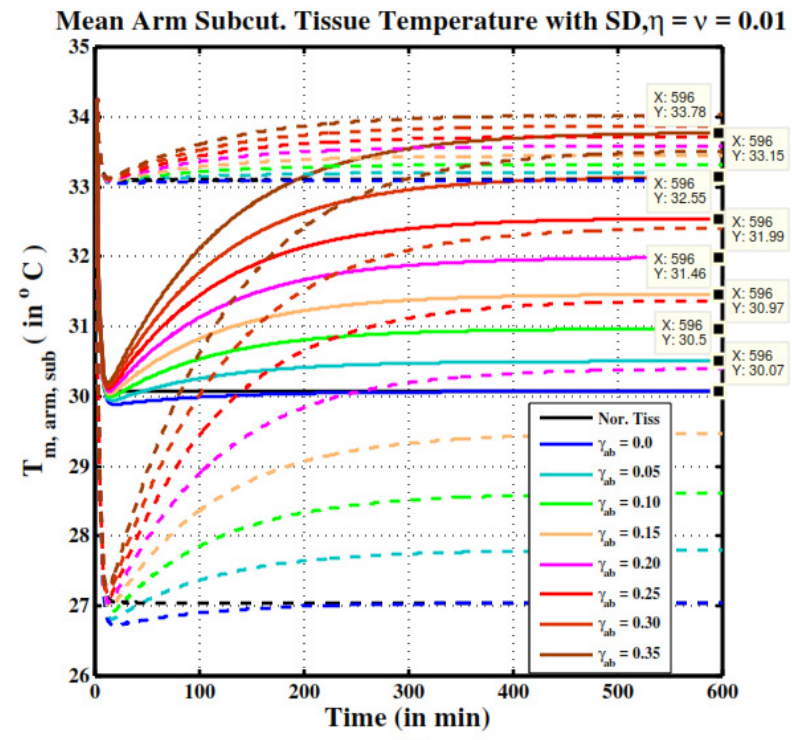

(b)

Figure 3. Mean arm (a) skin and (b) subcutaneous tissue temperature \pm SD versus time $t$ graph at $\eta=v=0.01$, in normal (black solid line) and abnormal tissue (coloured solid line) at different values of $\gamma_{\mathrm{ab}}( \pm \mathrm{SD}$ has been shown with dashed line)

$30.07^{\circ} \mathrm{C}$ in Figure $3(\mathrm{~b}), 5(\mathrm{~b})$ and $32.04^{\circ} \mathrm{C}$ in Figure $4(\mathrm{~b})$, 6(b) respectively. It is explained on the basis of heat loss through conduction for inner tissues and through convection and radiation for surface tissues. As soon as skin surface (initially at $34.12^{\circ} \mathrm{C}$ for arm and $35.30^{\circ} \mathrm{C}$ for leg) comes in contact with the atmosphere which is at lower temperature $\left(T_{a t m}=15^{\circ} \mathrm{C}\right)$, more heat is lost from the surface tissues due to high temperature gradient at skin surface. Skin surface temperature obtained in the present study, though significantly different from the results obtained previously ${ }^{20,21}$, matches well with the experimental results of ${ }^{17}$. The differences in temperature profiles of normal tissue from the previous study performed are due to the modifications done in the present study (mentioned in section 2.2) over the previous study.Mean normal skin temperature of armand leg is validated from ${ }^{17}$ using t-test at $1 \%$ level of significance ( $p>0.01$, confidence interval $(25.09,25.97))$ and at $5 \%$ level of significance $(\mathrm{p}=0.8256$, confidence interval $(28.15,28.61))$.

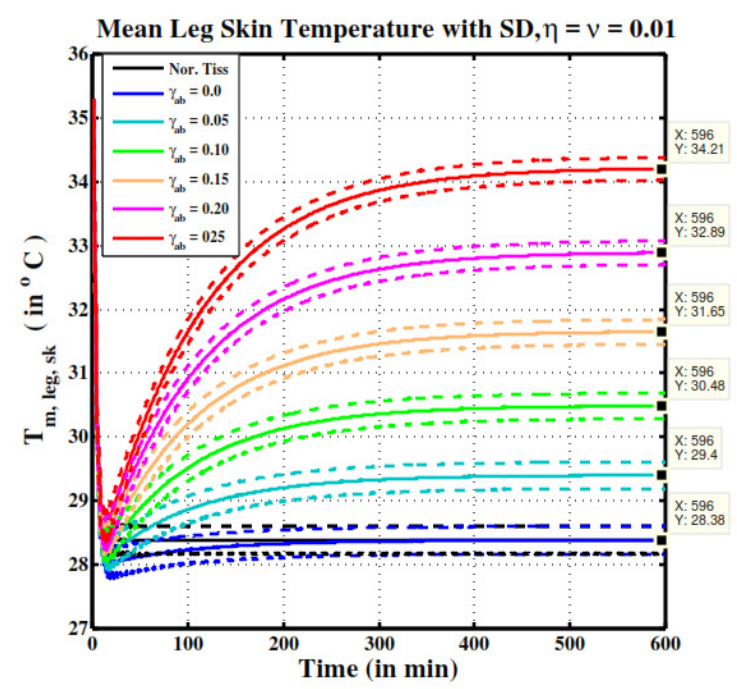

(a)

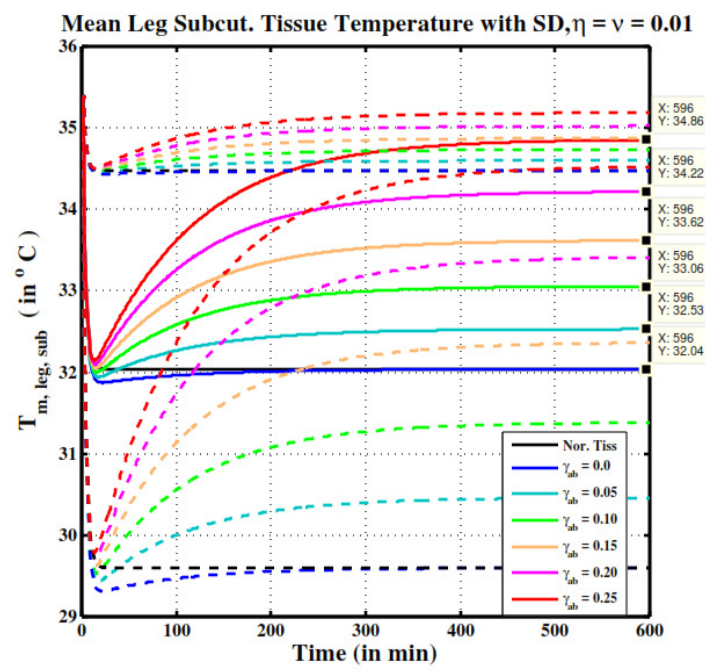

(b)

Figure 4. Mean leg (a) skin and (b) subcutaneous tissue temperature \pm SD versus time $t$ graph at $\eta=v=0.01$, in normal (black solid line) and abnormal tissue (coloured solid line) at different values of $\gamma_{\mathrm{ab}}( \pm \mathrm{SD}$ has been shown with dashed line) 


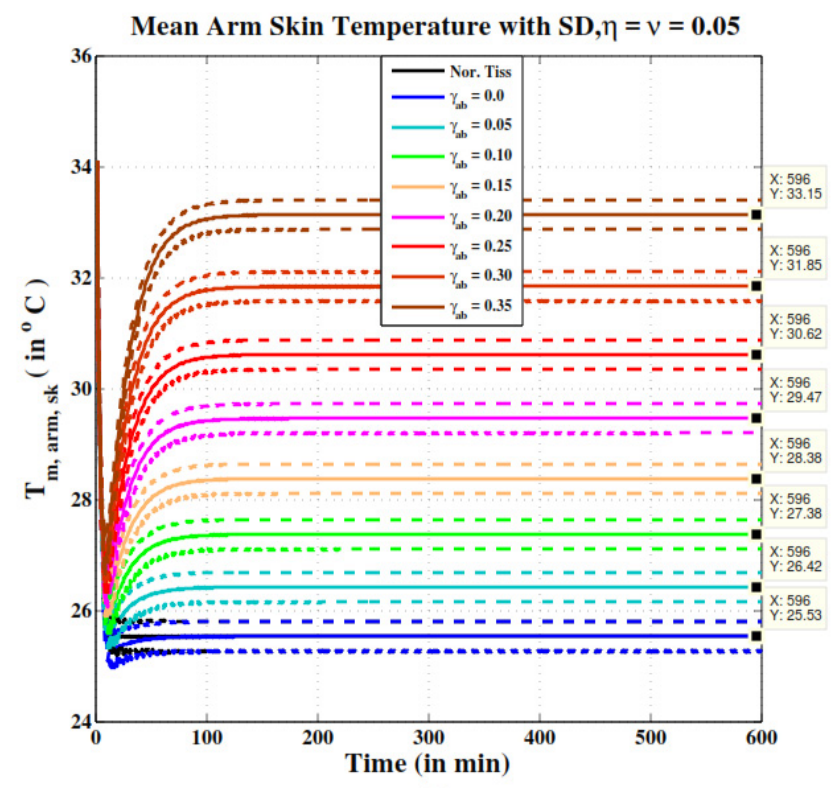

(a)

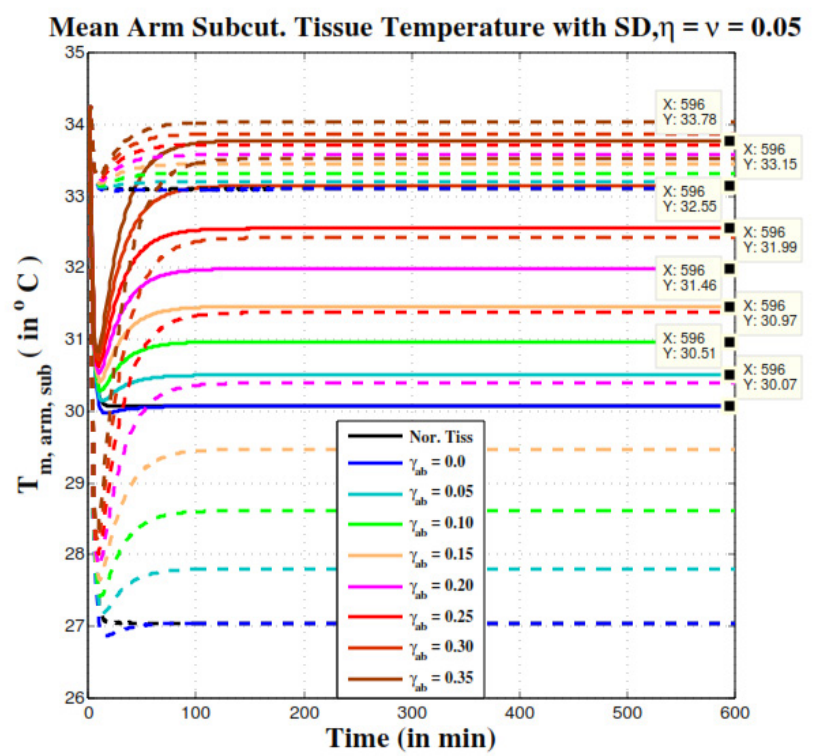

(b)

Figure 5. Mean arm (a) skin and (b) subcutaneous tissue temperature \pm SD versus time $t$ graph at $\eta=v=0.05$, in normal (black solid line) and abnormal tissue (coloured solid line) at different values of $\gamma_{\mathrm{ab}}( \pm \mathrm{SD}$ has been shown with dashed line)

Clean Surgical Wound:- It is observed that for $\eta=$ 0.01 , mean skin and subcutaneous tissue temperature of clean surgical wound $\left(\gamma_{\mathrm{ab}}=0\right.$, blue solid line)fall further by approx. $0.4^{\circ} \mathrm{C}$ and $0.2^{\circ} \mathrm{C}$ respectively in arm is shown in Figure 3(a,b)) and leg Figure $4(a, b)$.This is due to the combined effect of vasoconstriction $\left(\right.$ at $15^{\circ} \mathrm{C}$ of ambient temperature) and hemostasis to stop loss of blood due to surgery (as explained in section 2.1).It is assumed that initially at $\mathrm{t}=0$, abnormal tissue have negligible blood perfusion rate which gradually increase with time to attain the normal value. It is modelled by incorporating an increasing function of time $\phi(t)$ in the expression of blood perfusion rate. Also the effect of the rate at which transient vasoconstriction take place is analysed by comparing the results of $\eta=0.01$ with $\eta=0.05$. For $\eta=0.05$, same behaviour of additional decrease in mean temperature of arm and leg skin and subcutaneous tissue is observed in Figure4-5(a,b)). But the magnitude of additional decrease is less (almost half) for $\eta=0.05$.Increase in the rate of re-assumption of normal blood perfusion rate reduces additional fall in mean temperature to almost half.

Also the time taken by clean surgical wound to resume normal temperature is reduced significantly when $\eta$ is increased from 0.01 to 0.05 .Temperature profile of clean surgical wound $\left(\gamma_{\mathrm{ab}}=0\right.$, blue solid line) show that initially they undergo fast decreasefor approximately 20-25 min and then reach steady state value in $180 \mathrm{~min}$ approximately for $\eta=0.01$ in Figure 3-4(a,b) and in 40 min approximately for $\eta=0.05$ Figure $5-6(a, b)$, whereas normal tissue attain steady state temperature distribution within 30-35 minutes.More time is required by clean surgical wound in comparison to normal tissue to reach normal temperature. This is because even after full activation of acute mechanisms of vasoconstriction, blood flow is gradually adjusted to original or higher value according to the metabolic need of the tissue ${ }^{29}$. Its purpose is to bring cells and molecules of necessary nutrients to the site of tissue damage ${ }^{29,34}$.A significant decrease in the time required to resume normal temperature, when $\eta$ is increased from 0.01 to 0.05 , is due to the faster rate at which vascular changes take place. But the resumed temperature value at thermal equilibrium is same for both values of $\eta$. For example it is $25.53^{\circ} \mathrm{C}, 28.38^{\circ} \mathrm{C}$ for arm skin is shown in Figure 3(a), 5(a))and leg skinFigure 4(a), 6(a) respectively. The effect of increase in $\eta$ value, which markedly reduces both: additional fall in tissue temperature and time required to attain normal temperature may be of use to biomedical scientists. Time taken by clean surgical wound for $\eta=0.05$ to resume normal temperature can be validated on the basis of the results of $\mathrm{R}$ Gannon that it takes 40 minutes for a freshly cleansed wound to return to normal temperature ${ }^{4}$. 
It should be noted that steady state mean skin temperature attained by the clean $\left(\gamma_{a b}=0\right)$ surgical wound in arm is shown in Figure 3(a)) and legFigure 4(a)is lower than $33^{\circ} \mathrm{C}$ which may delay healing ${ }^{4}$. This situation can be avoided by providing heat externally ${ }^{5}$.

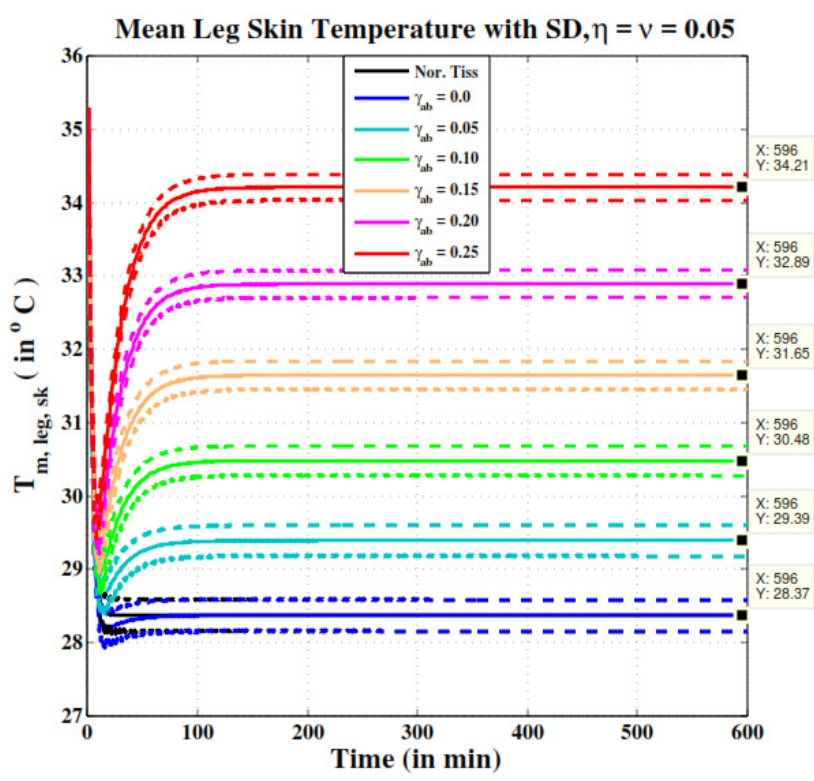

(a)

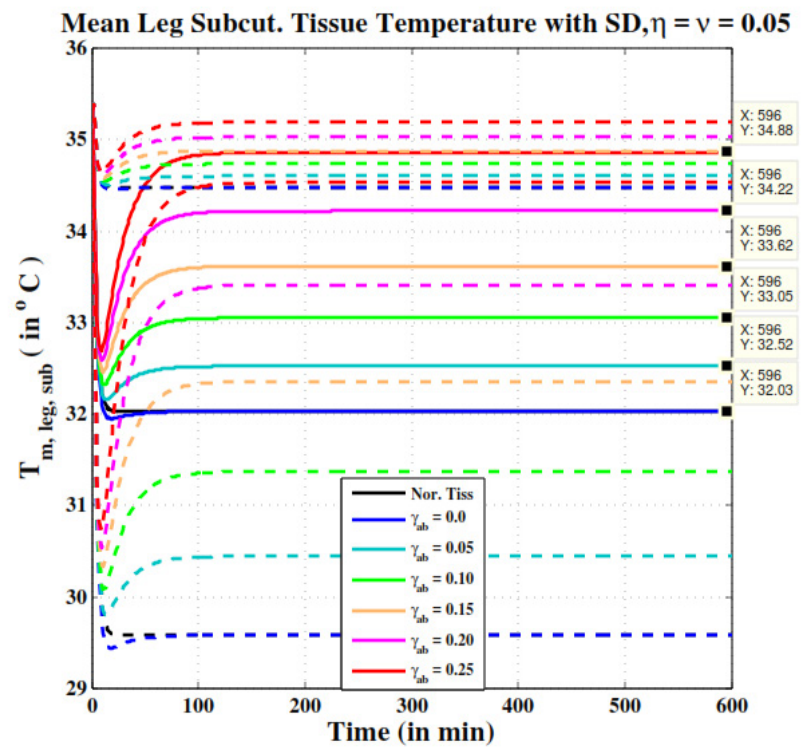

(b)

Figure 6. Mean leg (a) skin and (b) subcutaneous tissue temperature $\pm S D$ versus time $t$ graph at $\eta=v=0.05$, in normal (black solid line) and abnormal tissue (coloured solid line) at different values of $\gamma_{\mathrm{ab}}$ ( \pm SD has been shown with dashed line)

Contaminated Surgical Wound:-Skin surface temperature of contaminated wound tissue $\left(\gamma_{\mathrm{ab}}>0\right)$ at different levels of vasodilation i.e. at different blood perfusion rates has been shown in Figure 2a and $2 \mathrm{~b}$ by coloured (except black and blue) solid lines for $\eta=0.01$ and dotted dash lines for $\eta=0.05$. Mean arm skin and subcutaneous tissue temperature \pm SD has been shown for $\eta=0.01,0.05$

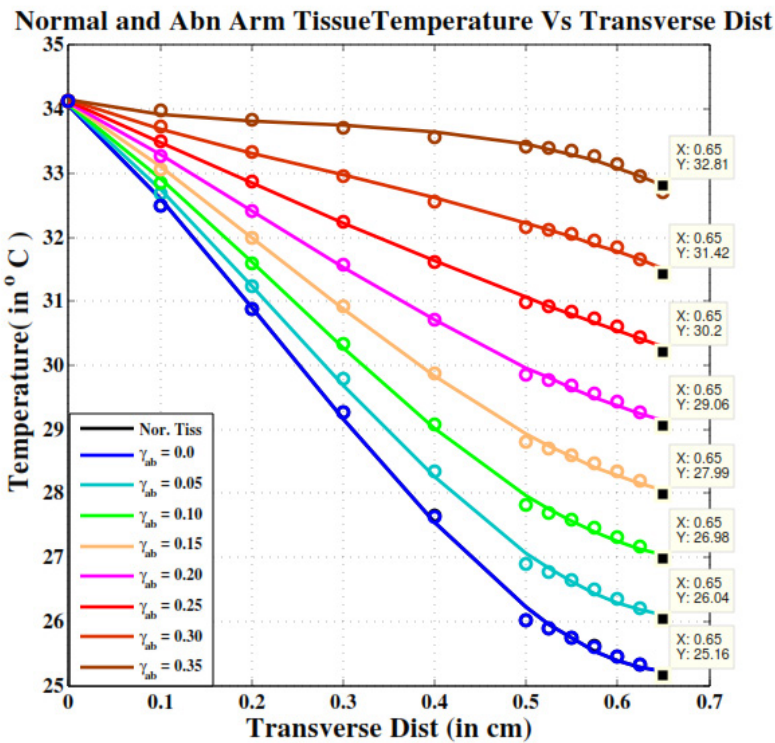

(a)

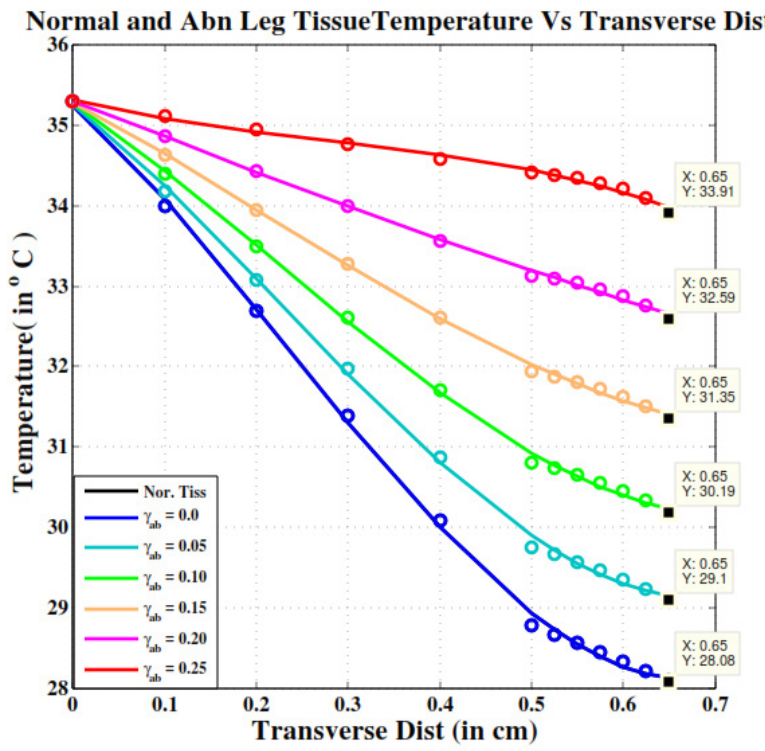

(b)

Figure 7. Normal and abnormal tissue temperature versus transverse distance (from core) in (a) arm and (b) leg for $\eta=$ $v=0.01$ in normal (black solid line; not visible as overlapped by blue solid line) and abnormal tissue (coloured solid line) at different values of $\gamma_{\mathrm{ab}}$. ${ }^{\circ}$ ' represent nodal temperature and solid line represent third degree polynomial curve fitted to nodal temperature data. Results for $\eta=v=0.05$ are not shown as temperature profiles at thermal equilibrium are same. 
in Figure $3 \mathrm{a}$ and $3 \mathrm{~b}$ and $5 \mathrm{a}$ and $5 \mathrm{~b}$ respectively.Mean leg skin and subcutaneous tissue temperature \pm SD has been shown for $\eta=0.01,0.05$ in Figure $4 a, 4 b$ and Figure $6 a, 6 b$ respectively. It can be seen Figure 3-6that for maximum $\gamma_{a b}$, the mean temperature does not exceed core body temperature as reported in clinical investigation by ${ }^{3}$.

Mean skin blood perfusion rate for arm and leg has been calculated from the available literature ${ }^{45}$ by dividing maximum skin blood flow at maximum vasodilation (in $\mathrm{cm}^{3} / \mathrm{hr}$ ) by corresponding tissue volume (in $\mathrm{cm}^{3}$ ). It has also been calculated for arm and leg mathematically for each value of $\gamma_{\mathrm{ab}}$ is shown in Figure 8a and 8b usingdiscretised form of eq.(2). Maximum mean skin blood perfusion rate at maximum vasodilation i.e. at $\gamma_{\mathrm{ab}}=0.35$ (for arm) and 0.25 (for leg) calculated theoretically is validated using t-test $(\mathrm{p}>0.08)$ (CI- $(0.0032,0.3442))$ in arm and $(\mathrm{p}>0.7)(\mathrm{CI}-(0.0024,0.2486))$ in leg respectively.

It is observed thatwith increase in $\gamma_{a b}$ (for both $\eta$ ), there is increase in steady state skin surface, mean skin and subcutaneous tissue temperature profile of contaminated wound. As shown in Figure 2a the arm skin surface temperature for $\gamma_{a b}=0.0(0.05) 0.35$ is $26.06,27$, $28,29.08,30.22,31.44,32.73$ respectively. Leg skin surface temperature in Figure 2(b)at $\gamma_{a b}=0.0(0.05) 0.25$ is 28.08, $29.1,30.2,31.36,32.6$, and 33.93 respectively. Similarly mean skin and subcutaneous tissue temperature of arm and leg can be observed in Figure $3 \mathrm{a}, 3 \mathrm{~b}, 6 \mathrm{a}$ and $6 \mathrm{~b}$ for $\eta=0.01$ and 0.05 . Increase in temperature with increase in $\gamma_{a b}$ is explained on the basis of vasodilation that could be achieved (explained in section 2.1) initially by acute control, followed by long term control depending upon the metabolic needs of the tissue ${ }^{29}$. Consequently the mean of the difference between skin temperature of nor-

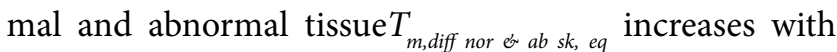
increase in $\gamma_{a b}$ Figure 9a and 9b. Maximum temperature difference at maximum vasodilationfor arm at maximum $\gamma_{\mathrm{ab}}=0.35$ is $7.6 \pm 0.07(7.53,7.67)$ and for leg at maximum $\gamma_{\mathrm{ab}}=0.25$ is $5.8 \pm 0.08(5.72,5.88)$. Validation of these results is done on the basis of clinical investigations of ${ }^{(3)}$. In this study skin temperature data were collected from legs of the subjects who were non-wounded (group 1 ), wounded non-infected (group 2a), and wounded infected (group $2 b$ ). In group $2 \mathrm{a}$ and $2 \mathrm{~b}$ only one of the two legs is wounded (the target site) and the other leg is treated as equivalent contralateral control site. This control site in their study is equivalent to the normal tissues in our study, wounded non-infected and wounded infected are equivalent to clean surgical wound and con- taminated surgical wound respectively in our study. The reported value of mean difference between temperatures of wounded non-infected and contralateral control site is $0.383^{\circ} \mathrm{C} \pm 0.893^{\circ} \mathrm{C}$ with confidence interval $\left(-0.51^{\circ} \mathrm{C}\right.$, $\left.1.276^{\circ} \mathrm{C}\right)$. Our results for clean surgical wound $\left(\gamma_{\mathrm{ab}}=0\right)$ at $\eta=0.01,0.05$ lie very well in the confidence interval. Similarly, skin temperature difference between infected
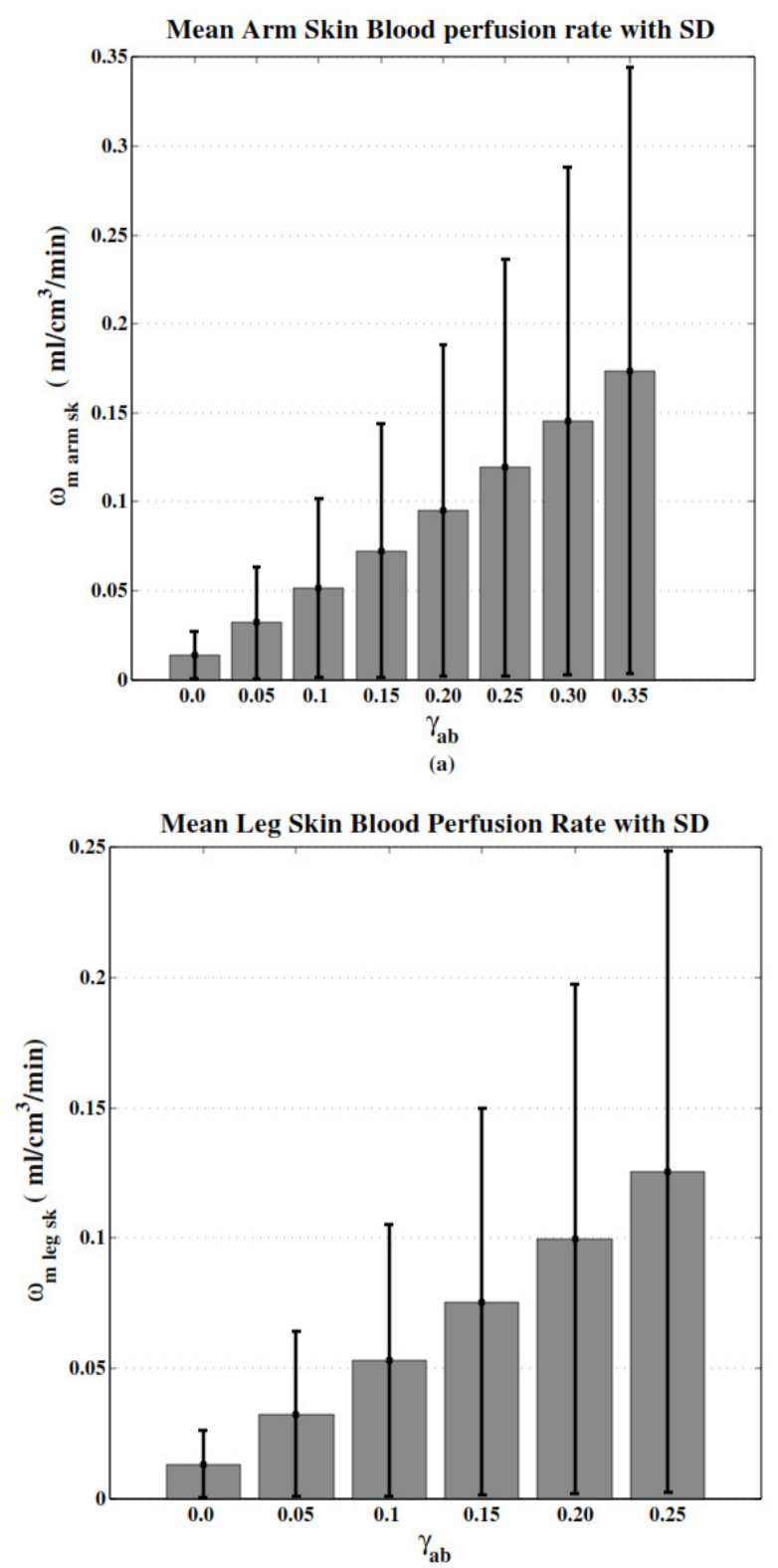

(b)

Figure 8. Mean blood perfusion rate of abnormal skin \pm SD (calculated theoretically using discretised form of equation (2)) versus linear coefficient of temperature dependence of blood perfusion $\left(\gamma_{\mathrm{ab}}\right)$ at $\eta=v=0.01$ in (a) arm and (b) leg. Results for $\eta=v=0.05$ are not shown as values at thermal equilibrium are same. 
wound and contralateral control site, as reported ${ }^{3}$ ranged from $-0.5^{\circ} \mathrm{C}$ to $8.7^{\circ} \mathrm{C}$ with mean $4.43^{\circ} \mathrm{C} \pm 2.44^{\circ} \mathrm{C}$ and confidence interval $\left(1.99^{\circ} \mathrm{C}, 6.87^{\circ} \mathrm{C}\right)$. Our results for difference in temperature of contaminated surgical wound $\left(\gamma_{\mathrm{ab}}>0\right)$ and normal tissue of leg lie well in the confidence interval $\left(1.99^{\circ} \mathrm{C}, 6.87^{\circ} \mathrm{C}\right)$. In case of arm our result lies in the reported range.

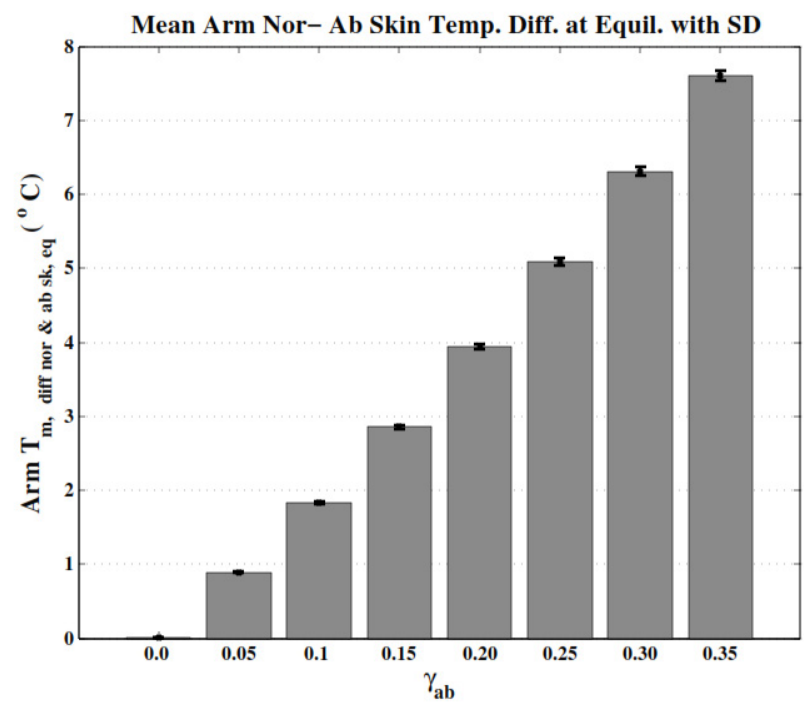

(a)

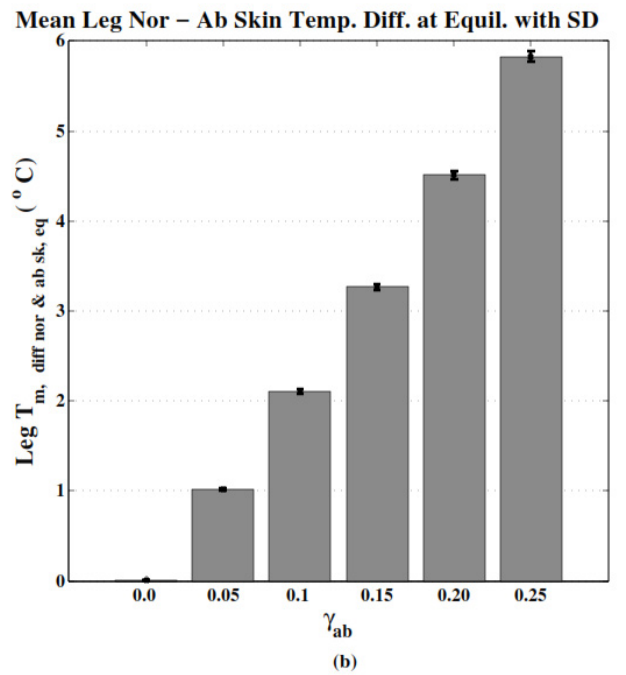

Figure 9. Graph between mean skin temperature difference

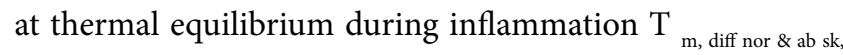
eq \pm SD and linear coefficient of temperature dependence of blood perfusion $\gamma_{\mathrm{ab}}$ in (a) arm and (b) leg at $\eta=v=$ 0.01. Results for $\eta=v=0.05$ are not shown as temperature differences at thermal equilibrium are same. $\left(\mathrm{T}_{\mathrm{m}}\right.$, diff nor \& ab sk, eq is calculated for each $\gamma_{a b}$, by taking mean of absolute difference in corresponding nodal temperature of abnormal and normal tissue when thermal equilibrium is reached).

Table 2a. Values of physical parameters

\begin{tabular}{|l|l|l|l|l|l|l|}
\hline Parameter & \multicolumn{2}{|l}{ Value } & Parameter & \multicolumn{2}{l|}{ Value } \\
\hline & Subcut. & Dermis & Epidermis & & Arm & Leg \\
\hline$K\left(\mathrm{Cal} / \mathrm{cm} / \mathrm{min} /{ }^{\circ} \mathrm{C}\right)$ & 0.023 & 0.07 & 0.07 & $\mathrm{~T}_{\text {befff }}\left({ }^{\circ} \mathrm{C}\right)$ & 34.12 & 35.30 \\
\hline$c\left(\mathrm{cal} / \mathrm{gm} /{ }^{\circ} \mathrm{C}\right)$ & 0.5497 & 0.8795 & 0.8795 & $\mathrm{~T}_{\mathrm{c}}\left({ }^{\circ} \mathrm{C}\right)$ & 34.12 & 35.30 \\
\hline$\rho\left(\mathrm{gm} / \mathrm{cm}^{3}\right)$ & 0.850 & 1.085 & 1.085 & $\mathrm{E}\left(\mathrm{Cal} / \mathrm{cm}^{2} / \mathrm{min}\right)$ & 0.007 & 0 \\
\hline $\mathrm{S}_{\text {bas }}$ & 0.000832 & 0.005277 & 0 & $\rho_{\mathrm{b}}\left(\mathrm{gm} / \mathrm{cm}^{3}\right)$ & 1.069 & 1.069 \\
\hline$\omega_{\mathrm{o}}{ }^{a}\left(\mathrm{ml} / \mathrm{min} / \mathrm{cm}^{3}\right)$ & 0.000216 & $.066^{b}, .063^{\mathrm{c}}$ & 0 & $\mathrm{c}_{\mathrm{b}}\left(\mathrm{Cal} / \mathrm{gm} /{ }^{\circ} \mathrm{C}\right)$ & 0.8724 & 0.8724 \\
\hline$T_{o}\left({ }^{\circ} \mathrm{C}\right)$ & $33.59^{\mathrm{b}}, 35.31^{\mathrm{c}}$ & $33.25^{\mathrm{b}}, 34.10^{\mathrm{c}}$ & $33.25^{\mathrm{b}}, 34.10^{\mathrm{c}}$ & & & \\
\hline
\end{tabular}

${ }^{\mathrm{a}}$ at thermo-neutrality, ${ }^{\mathrm{b}}$ arm, ${ }^{\mathrm{c}}$ leg

Table 2b. Calculated values of parameters used in this study

\begin{tabular}{|c|c|c|c|c|c|c|c|}
\hline Parameter & Tissue & Arm & Leg & Parameter & Tissue & Arm & Leg \\
\hline \multirow{3}{*}{$\begin{array}{l}\omega_{\circ}^{*} \\
\left(\mathrm{ml} / \mathrm{min} / \mathrm{cm}^{3}\right)\end{array}$} & Subcut. & 0.000108 & 0.000108 & \multirow{3}{*}{$\begin{array}{l}s_{2} \\
\left(\mathrm{Cal} / \mathrm{cm}^{3} / \mathrm{min} /{ }^{\circ} \mathrm{C}\right)\end{array}$} & Subcut. & $5.6189 \mathrm{e}-06$ & $4.9874 \mathrm{e}-06$ \\
\hline & Dermis & 0.033 & 0.0315 & & Dermis & $4.5627 \mathrm{e}-05$ & $3.4413 e-05$ \\
\hline & Epider. & 0.0 & 0.0 & & Epider. & 0 & 0 \\
\hline \multirow{3}{*}{$\begin{array}{l}\mathrm{s}_{1} \\
\left(\mathrm{Cal} / \mathrm{cm}^{3} / \mathrm{min}\right)\end{array}$} & Subcut. & $8.1064 \mathrm{e}-5$ & $7.1953 \mathrm{e}-5$ & \multirow{3}{*}{$\begin{array}{l}\text { Outer radius }{ }^{* *} \\
(\mathrm{~cm})\end{array}$} & Subcut. & 5.0 & 5.3 \\
\hline & Dermis & $6.5825 \mathrm{e}-4$ & $4.9647 \mathrm{e}-4$ & & dermis & 5.125 & 5.425 \\
\hline & Epider. & 0 & 0 & & Epider. & 5.15 & 5.45 \\
\hline$\eta(=v)$ & - & $0.01,0.05$ & $0.01,0.05$ & $\gamma_{a b}$ & - & $0.0(.05) 0.35$ & $0.0(.05) 0.25$ \\
\hline
\end{tabular}

${ }^{*}$ at $15^{\circ} \mathrm{C},{ }^{* *}$ assumed 
Again it is noted that skin temperature attained by arm and leg for $\gamma_{\mathrm{ab}} \leq 0.30$ and 0.20 respectively is less than $33^{\circ} \mathrm{C}$.It is below the appropriate surface temperature range required for proper healing ${ }^{4}$.

In this study, mean of maximum blood perfusion rate calculated theoretically using eq. (2) for $\gamma=0.35$ (arm), 0.25 (leg) at thermal equilibrium comes out to be $0.1737 \pm 0.1705$ with confidence interval $(0.0032,0.3442)$ for arm and $0.1255 \pm 0.1231$ with confidence interval $(0.0024,0.2486)$ for leg. The maximum blood perfusion rate $\left(0.3231 \mathrm{~cm}^{3} / \mathrm{hr} / \mathrm{cm}^{3}\right.$ for arm and $0.1435 \mathrm{~cm}^{3} / \mathrm{hr} / \mathrm{cm}^{3}$ for leg) obtainedby dividing the reported value $\mathrm{e}^{45}$ of maximum blood flow at maximum vasodilation of arm (leg) by the tissue volume of arm (leg) lies in respective confidence interval mentioned above. The mean difference in temperature of contaminated surgical wound at this maximum blood perfusion rate and the normal tissue lie well in the range $\left(-0.5^{\circ} \mathrm{C}, 8.7^{\circ} \mathrm{C}\right)$ reported by ${ }^{3}$. This validates the present study done.

Further it is reported ${ }^{3}$ that a significant relationship exist between an increased skin temperature of greater than $2^{\circ} \mathrm{C}$ difference and infected wound. From Figure 9a and $9 \mathrm{~b}$ it can be seen that for both arm and leg, $\mathrm{T}_{\mathrm{m} \text {, diff nor \& }}$ abs k, eq greater than $2^{\circ} \mathrm{C}$ corresponds to $\gamma_{a b}>0.1$ approximately. But arm skin temperature for $0.1<\gamma_{a b}<0.30$ Figure $3(\mathrm{a}), 5(\mathrm{a})$ is less than $33^{\circ} \mathrm{C}$, which is below the appropriate surface temperature range required for proper healing ${ }^{4,5}$. Same is the case for leg skin temperature for $0.1<\gamma_{a b}<0.20$ Figure $4 \mathrm{a}$ and $6 \mathrm{a}$.This information can be used to plan future medication so that healing is not delayed.

Also the mean blood perfusion rate is shown in Figure8 $\mathrm{a}$ and $8 \mathrm{~b}$ and difference in abnormal and normal tissue temperature at thermal equilibrium during inflammation $T_{\text {diff, eq }}$ in Figure $15(\mathrm{a}-\mathrm{c})$ ) is almost same forall $\eta=$ $0.01,0.05$ (results not shown). This is because once complete vasodilation is attained (no matter with whatever speed), the blood perfusion rate and thus $T_{d i f f e q}$ at equilibrium will remain same for fixed $\gamma_{a b}$.

\section{Conclusion}

Analysis of temperature profiles of normal as well as abnormal peripheral tissues of human limb undergoing inflammation via hemostasis has been done. A non linear mathematical model has been developed to simulate skin surface, mean skin and mean subcutaneous temperature,mean of difference between normal tissue temperature and inflamed tissue temperature, and mean perfusion rate of the peripheral tissues during inflammation are simulated.Results have been validated with the experimental studies performed. It is concluded that the effect of vasodilation on thermal variations is modelled accurately by considering blood perfusion rate dependent linearly on local tissue temperature, approximating metabolic heat generation rate linearly dependent on temperature from Van't Hoff $\mathrm{Q}_{10}$ effect with a sensitivity coefficient of two and improving upon the values of other physical parameters as discussed in the paper.

Future work will extend the present one dimensional model to two dimensional model to take into consideration the anatomy of blood vessels in the core of peripheral tissues.

This study may help in identifying the difference between healing and non-healing wounds via thermal information available from this model. This may also be useful to biomedical scientists in diagnosis and development of treatment regimen for surgical wounds to prevent it from turning into a chronic wound.

\section{Conflict of Interest statement}

We declare that there are no issues that may be considered potential conflicts of interest to this work.

\section{References}

1. Li J, Chen J, Kirsner R. Pathophysiology of acute wound healing. Clinics in dermatology. 2007; 25(1): 9-18. Availavle from: Crossref Mid:17276196

2. Diegelmann RF, Evans MC. Wound healing: An overview of acute, fibrotic and delayed healingFront Bioscience. 2004; 9(1): 283-9.

3. Fierheller M, Sibbald RG. A clinical investigation into the relationship between increased periwound skin temperature and local wound infection in patients with chronic leg ulcers. Advances in skin and wound care. 2010; 23(8):36979. Available from: Crossref PMid:20631603

4. Gannon R. Fact file: Wound cleansing: sterile water or saline?Nursing Times net. 2007; 103(9): 44.

5. Tweed C. A review of the literature examining the relationship between temperature and infection in surgical wound healing. 2003.

6. Kengne E, Hamouda FB, Lakhssassi A. Extended Generalized Riccati Equation Mapping for Thermal 
Traveling-Wave Distribution in Biological Tissues through a Bio-Heat Transfer Model with Linear/Quadratic Temperature-Dependent Blood Perfusion. Applied Mathematics. 2013; 4(10): 1471. Available from: Crossref

7. Pennes HH. Analysis of tissue and arterial blood temperatures in the resting human forearm. Journal of applied physiology. 1948; 1(2): 93-122. PMid:18887578

8. Henriques F, Moritz A. Studies of thermal injury: I. The conduction of heat to and through skin and the temperatures attained therein. A theoretical and an experimental investi-

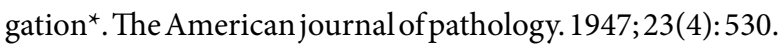
PMid:19970945 PMCid:PMC1934298

9. Shih T-C, Yuan P, Lin W-L, Kou H-S. Analytical analysis of the Pennes bioheat transfer equation with sinusoidal heat flux condition on skin surface. Medical Engineering and Physics. 2007; 29(9): 946-53. Available from: Crossref PMid:17137825

10. Perl W. An extension of the diffusion equation to include clearance by capillary blood flow. Annals of the New York Academy of Sciences. 1963; 108(1): 92-105. Available from: Crossref PMid:13942460

11. Lang J, Erdmann B, Seebass M. Impact of nonlinear heat transfer on temperature control in regional hyperthermia. Transactions on Biomedical Engineering, IEEE 1999; 46(9): 1129-38.

12. Wissler EH. Pennes' 1948 paper revisited. Journal of Applied Physiology. 1998; 85(1): 35-41. PMid:9655751

13. Saxena V, Bindra J. Quadratic shape functions in variational finite element approach to heat distribution in cutaneous and subcutaneous tissues. Indian Journal of pure Applied Mathematics. 1987; L_8 (9): 846-55.

14. Kengne E, Lakhssassi A, Vaillancourt R, editors. Temperature distribution in living biological tissue simultaneously subjected to oscillatory surface and spatial heating: Analytical and numerical analysis. International Mathematical Forum. 2012.

15. Pardasani K, Shakya M. Three dimensional infinite element model to study thermal disturbances in human peripheral region due to tumor. Journal of Biomechanics. 2006; 39: 634. Available from: Crossref

16. Gowrishankar T, Stewart DA, Martin GT, Weaver JC. Transport lattice models of heat transport in skin with spatially heterogeneous, temperature-dependent perfusion. BioMedical Engineering OnLine. 2004; 3(1): 1. Available from: Crossref, Crossref PMid:14746653 PMCid:PMC343291

17. Werner J, Reents T. A contribution to the topography of temperature regulation in man. European journal of applied physiology and occupational physiology. 1980; 45(1): 87-94. Available from: Crossref

18. Jain M, Shakya M. Study of temperature variation in human peripheral region during wound healing process due to plastic surgery. Applied Mathematical Sciences. 2009; 3(54): 2651-62.

19. Jain M, Shakya M. An infinite element model to study temperature variations during wound healing process after plastic surgery. Infinite Dimensional Analysis, Quantum Probability and Related Topics. 2011; 14(02): 209-24. Available from: Crossref

20. Gupta N, Shakya M. Transient State Finite Element Model to Analyse Thermal Variations in Peripheral Region of Human Limb undergoing Healing after Surgery. IOSR Journal of Mathematics (IOSR-JM) 2014; 10(6): 66-75.

21. Gupta N, Shakya M. A Two-Dimensional Mathematical Model to Analyze Thermal Variations in Skin and Subcutaneous Tissue Region of Human Limb during Surgical Wound Healing. Applied Mathematics. 2016; 7(02): 145. Available from: Crossref

22. Kamel C, McGahan L, Mierzwinski-Urban M, Embil Journal of Classification of surgical wounds. 2011.

23. Fiala D, Lomas KJ, Stohrer M. A computer model of human thermoregulation for a wide range of environmental conditions: the passive system. Journal of Applied Physiology. 1999; 87(5): 1957-72. PMid:10562642

24. Fiala D, Havenith G, Bröde P, Kampmann B, Jendritzky G. UTCI-Fiala multi-node model of human heat transfer and temperature regulation. International journal of biometeorology. 2012; 56(3): 429-41. Available from: Crossref PMid:21503622

25. Stolwijk JA. A mathematical model of physiological temperature regulation in man. 1971.

26. de Dear RJ, Arens E, Hui Z, Oguro M. Convective and radiative heat transfer coefficients for individual human body segments. International Journal of Biometeorology. 1997; 40(3):141-56.Available from: Crossref PMid:9195861

27. Deodhar AK, Rana R. Surgical physiology of wound healing: a review. Journal of Postgraduate Medicine. 1997; 43(2): 52. PMid:10740722

28. Chin GA, Diegelmann RF, Schultz GS. Cellular and molecular regulation of wound healing. Basic and Clinical Dermatology. 2005; 33:17.

29. Hall JE. Guyton and Hall Textbook of Medical Physiology: Enhanced E-book: Elsevier Health Sciences; 2010.

30. Johnson JM, Minson CT, Kellogg DL. Cutaneous vasodilator and vasoconstrictor mechanisms in temperature regulation. Comprehensive Physiology. 2014. Available from: Crossref PMid:24692134

31. Kellogg D. In vivo mechanisms of cutaneous vasodilation and vasoconstriction in humans during thermoregulatory challenges. Journal of Applied Physiology. 2006; 100(5):1709-18. Available from: Crossref PMid:16614368

32. Charkoudian N. Mechanisms and modifiers of reflex induced cutaneous vasodilation and vasoconstriction in 
humans. Journal of Applied Physiology. 2010; 109(4):12218. Available from: Crossref PMCid:PMC2963327

33. Amiya E, Watanabe M, Komuro I. The relationship between vascular function and the autonomic nervous system. Annals of vascular diseases. 2014; 7(2):109. Available from: Crossref PMid:24995054 PMCid:PMC4072858

34. Kumar V, Abbas AK, Fausto N, Mitchell RN. Robbins basic pathology: Elsevier Health Sciences; 2012.

35. Upchurch J. SIRS and sepsis: When the immune system turns traitor 2011.2015.

36. Gaffney E, Pugh K, Maini P, Arnold F. Investigating a simple model of cutaneous wound healing angiogenesis. Journal of mathematical biology. 2002; 45(4): 337-74. Available from: Crossref PMid:12373343

37. Maggelakis SA. A mathematical model of tissue replacement during epidermal wound healing. Applied Mathematical Modelling. 2003; 27(3):189-96. Available from: Crossref

38. Klabunde R. Cardiovascular physiology concepts: Lippincott Williams and Wilkins; 2011.
39. Ignarro LJ. Endothelium-derived nitric oxide: actions and properties. The FASEB Journal. 1989; 3(1):31-6. PMid:2642868

40. Alberts B, Bray D, Hopkin K, Johnson A, Lewis J, Raff M, et al. Essential cell biology: Garland Science; 2013.

41. Wang X L. Convective heat losses from segments of the human body. Climate Buildings. 1990; 3:8-14.

42. Wang X. Convective heat transfer coefficients from head and arms. Climate Buildings. 1990; 2:3-7.

43. Wang X-L. Free convective heat transfer coefficients of a heated full-scale manikin. Climate Buildings. 1990; 1:1731.

44. Kenny GP, Sigal RJ, McGinn R. Body temperature regulation in diabetes. Temperature. 2016;3(1):119-45. Available from: Crossref PMid:27227101 PMCid:PMC4861190

45. Salloum M, Ghaddar N, Ghali K. A new transient bioheat model of the human body and its integration to clothing models. International Journal of Thermal Sciences. 2007; 46(4):371-84. Available from: Crossref 